\title{
Revision of the St. Louis Federal Reserve's Adjusted Monetary Base
}

\author{
R. ALTON GILBERT
}

$\mathrm{T}$

HE adjusted monetary base is designed to be a single measure of all Federal Reserve actions that influence the money stock, including effects of changes in reserve requirements. It is equal to the source base plus a reserve adjustment magnitude (RAM) that accounts for changes in reserve requirements by the Federal Reserve.

The adjusted monetary base calculated by this Bank is being revised as a result of changes in the structure of reserve requirements under the Monetary Control Act of 1980 (MCA), which became effective in November $1980 .^{1}$ This article explains the reasons for the revision and describes the process used to calculate the RAM.

\section{REASONS FOR REVISING THE ADIUSTED MONETARY BASE}

RAM measures the impact of changes in reserve requirements by simply subtracting the current period's required reserves from those that would have been required if some base period's reserve requirements were, instead, in effect. Using a fixed base period for calculating RAM, however, creates difficulties whenever there is a major change in the structure of reserve requirements. If the method of classifying deposits for reserve requirement purposes has been significantly changed since the base period, it may be impossible to calculate required reserves with the base period reserve requirements. In essence, the deposit

\footnotetext{
Two measures of monetary base adjusted for reserve requirement changes are published by the Federal Reserve System. The series described here is published by the Federal Reserve Bank of St. Louis; another series is published by the Board of Governors of the Federal Reserve System. For a comparison of these measures, see Albert E. Burger, "Alternative Measures of the Monetary Base," this Review (June 1979), pp. 3-8.
}

data reported under the new requirements may simply be insufficient to compute the base period required reserve measure.

When the adjusted monetary base (AMB) was revised previously, the base period chosen was $1935 .^{2}$ Use of 1935 reserve requirement ratios, however, created problems for calculating RAM following the major change in the structure of reserve requirements on net demand deposits in November 1972. At that time, the structure of reserve requirements on a member bank's net demand deposits was changed from one based on bank location to one based on the size of total net demand deposits. Regardless of a member bank's location, its required reserves on net demand deposits became a certain percentage of the first $\$ 2$ million in net demand deposits, a higher percentage of the next $\$ 8$ million, and so forth.

To have been able to accurately calculate RAM on net demand deposits after November 1972 using the 1935 base period would have required information on the distribution of net demand deposits both by location of member banks (in reserve cities, central reserve cities, and at country banks) and by size categories. However, that information was not available after 1972. The solution to this problem involved holding constant the distribution of net demand deposits by location of member banks as of November 1972 for purposes of calculating RAM after this date. Subsequent changes in the geographic distribution of net demand deposits among member banks served to dis-

\footnotetext{
2 Albert E. Burger and Robert $\mathbf{H}$. Rasche, "Revision of the Monetary Base," this Review (July 1977), pp. 13-28. This article refers to 1929 as the base year. After the article was published, however, it was discovered that the reserve requirements used as base period requirements were not actually in effect until 1935.
} 
tort somewhat the measurement of RAM on net demand deposits using the 1935 base period. $^{3}$

Changes in the structure of reserve requirements under the MCA have created even more problems for the use of 1935 as the base period. The category of checkable deposits subject to reserve requirements has been changed from net demand deposits to net transaction deposits, which include net demand deposits plus other checkable deposits. ${ }^{4}$ The initial structure of reserve requirements on this category of deposits will be 3 percent on the first $\$ 25$ million and 12 percent on deposits over that amount; in addition, the $\$ 25$ million level will be changed each year, with a percentage change equal to 80 percent of the percentage change in total transaction deposits in the nation.

Another factor that makes the structure of reserve requirements more complicated under the MCA is that reserve requirements are phased in. Member bank reserve requirements are changed gradually over four years from those in effect prior to November 1980 to those specified in the MCA, and the reserve requirements of nonmembers are phased in over eight years. Consequently, the structure of reserve requirements and the categories by which deposits are reported for reserve requirement purposes are substantially different from those that existed prior to November 1980 .

Unfortunately, the problem with calculating RAM cannot be solved simply by selecting a base period other than 1935. There is no period with a structure of reserve requirements that is appropriate to use as base reserve requirements. With the new structure of reserve requirements under the $\mathrm{MCA}$ and the limitation on deposit data by reserve requirement categories, the deposit information that would be required is simply not available.

\section{BASTC PEATUES OF TRE NEW NETHOD}

There is, however, an alternative way to compute RAM that avoids the problems discussed above. The crucial criterion for the RAM base period is that its reserve requirements can be used to calculate the base period total required reserves for deposits at any point in time. This means that the base period reserve requirements do not have to be tied to a specific

\footnotetext{
3ee John A. Tatom, "Issues in Measuring a Reserve Adjustment Magnitude," this Review (January 1981), pp. 11-29.

* Other checkable deposits include NOW and ATS accounts, which were classified as savings deposits for reserve requirement purposes prior to November 1980 and were subject to a 3 percent reserve requirement.
}

structure of reserve requirement ratios. The base period reserve requirements used here are average reserve requirements in the base period on various categories of deposit liabilities.

One category of deposit liabilities subject to reserve requirements in the base period is total transaction deposits; the other is total time and savings deposits. Required reserves are calculated by multiplying the average reserve requirements in the base period by total deposits in these two categories.

The base period reserve requirements on transaction deposits is 12.66 percent, which is the average reserve requirement on net transaction deposits subject to reserve requirements for the period January 1976 through August 1980. The base period reserve requirement on time and savings deposits is 3.20 percent, which is the average reserve requirement on total time and savings deposits of member banks (excluding NOW and ATS accounts) over the same period.

\section{SOME SPECIAL CONSIDERATIONS}

Depository Institutions to be Included in Calcalating RAM: Initially Only Member Banks

Although the MCA extends reserve requirements of the Federal Reserve to all depository institutions offering transaction deposits or nonpersonal time deposits, the RAM measure presented in this paper uses only member bank deposit liabilities and required reserves. Including total deposit liabilities and required reserves of all depository institutions would cause RAM to rise, at least initially, since the reserve requirements on nonmembers are being phased in over an eight-year period at a rate of one-eighth of the final MCA requirements per year. ${ }^{5}$ Since almost all nonmember depository institutions will meet their initial required reserves with their vault cash, the imposition of reserve requirements on nonmember institutions has no effect on the amount of deposit liabilities the banking system can create with a given source base. ${ }^{6}$

Including the deposit liabilities and required reserves of nonmembers in the calculation of RAM would produce a spurious movement in the ratio of

\footnotetext{
${ }^{5}$ RAM would rise in the first year simply because base period reserve requirements are higher than one-eighth of the reserve requirement ratios under the MCA.

6 RAM will have to be revised within the next few years to include the deposit liabilities and required reserves of nonmember institutions. The appropriate time for such a revision will be when nonmenber institutions begin changing their holdings of reserves in response to changes in their required reserves.
} 
M1B to the AMB. First, there may be problems with receiving accurate reports from new reporting depository institutions. Second, nonmember institutions with deposits of less than $\$ 2$ million are exempt both from reporting and from meeting reserve requirements until May 1981, and those with deposits between $\$ 2$ and $\$ 15$ million are to report and meet reserve requirements quarterly beginning on a staggered basis in January 1981. Extension of reserve requirements to these additional institutions would reduce the ratio of M1B to AMB several times between November 1980 and May 1981, if data for nonmembers were used in the RAM calculation. Finally, RAM would decline, and the ratio of M1B to AMB would increase each September for seven years when reserve requirements of nonmembers are increased. Such changes in the ratio of M1B to $A M B$ due to the phase-in of reserve requirements on nonmembers would diminish the value of the $A M B$ as a measure of Federal Reserve actions affecting the money stock.

Reserve requirements of member banks will be reduced gradually to those specified in the MCA, with the first reduction having occurred in November 1980. Reductions in member bank reserve requirements will reduce the demand for reserves by the banking system for a given level of transaction deposits. The reserves released will be captured in the RAM measure.

\section{Categories of Deposit Liabilities Subject to Reserve Requirements in the Base Period}

In calculating required reserves under the base period reserve requirements, deposit liabilities are divided into two categories:

(1) total transaction deposits, including net demand deposits and NOW and ATS accounts, and

(2) time and other savings deposits.

Transaction Deposits-Some member banks were authorized to offer NOW accounts in 1973, and all were authorized to offer ATS accounts in November 1978. Prior to November 1980, NOW and ATS accounts were classified as savings deposits for purposes of reserve requirements and were subject to a 3 percent reserve requirement. Authorization for member banks to offer NOW and ATS accounts can be viewed as a regulatory action affecting reserve requirements on transaction deposits. As individuals shifted demand deposits to interest-bearing NOW and ATS accounts, the banking system could support a larger level of M1B with a given source base. Shifts of demand deposits to NOW and ATS accounts at member banks caused RAM to rise by the amount of reserves released and, therefore, did not cause the ratio of M1B to AMB to change.

After full phase-in of reserve requirements specified in the MCA, reserve requirements on net demand deposits and NOW accounts will be identical. Deposit shifts from demand deposits to NOW accounts, therefore, will not affect required reserves and will have no effect on either M1B or AMB.

Total Time and Savings Deposits-Only those time and savings deposits classified as nonpersonal deposits are subject to reserve requirements under the $\mathrm{MCA}^{7}$ If the base period's reserve requirements applied only to nonpersonal time and savings deposits, calculation of RAM prior to November 1980 would be impossible; no information is available on this deposit category before that date. Information on total time and savings deposits (excluding member bank NOW and ATS accounts) does exist prior to November 1980, however, and this information will also be available after November 1980. Therefore, total time and savings deposits at member banks (excluding NOW and ATS accounts), rather than nonpersonal time and savings deposits, are used as the other category of deposit liabilities subject to reserve requirements in the base period.

\section{Timing of Deposit Liabilities and Required Reserves}

Prior to September 1968, a member bank's required reserves in each settlement week were based on its deposit liabilities for the same week. Calculation of RAM until September 1968 reflects contemporaneous reserve accounting by using deposit liabilities and required reserves of the same week in calculating RAM.

Under lagged reserve accounting, which has been in effect since September 1968, a member bank's required reserves each week are based on its deposit liabilities two weeks earlier. After September 1968, RAM is calculated each week using required reserves of the current week and deposit data for two weeks earlier.

\section{Counting Vault Cash as Reserves}

Until December 1959, member banks could use only their reserve balances at Federal Reserve Banks to satisfy their reserve requirements. The Federal

\footnotetext{
7 A nonpersonal time deposit is a time or savings deposit representing funds in which any beneficial interest is held by a depositor other than a natural person, or a time deposit that is transferable. A time deposit is transferable unless the deposit agreement contains a specific statement to the cortrary.
} 
Reserve began counting various amounts of member bank vault cash as reserves in December 1959 and, by December 1960, the entire amount of member bank vault cash was counted as reserves. As more vault cash was counted as reserves, the existing source base could support more deposit liabilities.

The RAM adjustment for the counting of vault cash as reserves involves subtracting from RAM the amount of member bank vault cash not counted as reserves by the Federal Reserve. For the period before December 1959 , total member bank vault cash is subtracted from RAM. Between December 1959 and December 1960, total vault cash, less the amount the Federal Reserve counted as reserves, is subtracted.

\section{COMPLETE SPECIFICATION OF THE NEW RAM}

The revised reserve adjustment magnitude is calculated as follows:

Prior to September 1968

$\begin{aligned} \mathrm{RAM}_{\mathrm{t}}= & 126640(\mathrm{TD})_{\mathrm{t}}+.031964(\mathrm{TS})_{t}-\mathrm{RR}_{\mathrm{t}} \\ & -\left(\mathrm{TVC}_{\mathrm{t}}-\mathrm{VCR}_{\mathrm{t}}\right)\end{aligned}$
After September 1968

$\mathrm{RAM}_{\mathrm{t}}=.126640(\mathrm{TD})_{\mathrm{t}-\mathrm{2}}+.031964(\mathrm{TS})_{\mathrm{t}-\mathrm{z}}-\mathrm{RR}_{\mathrm{t}}$

where RAM is reserve adjustment magnitude for the current week; TD is member bank transaction deposits subject to reserve requirements; TS is total time and savings deposits at member banks; RR is member bank required reserves; TVC is total member bank vault cash; and VCR is member bank vault cash counted as reserves. ${ }^{8}$

\section{THE DATA}

Levels and growth rates of the new AMB series are presented in tables 1 and 2 . For contrast, monthly and quarterly levels and growth rates of the old AMB series are presented in tables 3 and 4. Data on the new and old series of adjusted bank reserves are presented in tables 5-8. Adjusted bank reserves are calculated by subtracting seasonally adjusted currency in the hands of the public from seasonally adjusted AMB. Additional data on the new series of AMB and adjusted bank reserves are available on request.

\footnotetext{
${ }^{8}$ Before December 1959, VCR $=0$. Beginning in December 1960, TVC $=$ VCR.
} 
Table 1

New Adjusted Monetary Base

(compounded annual rates of change, seasonally adjusted)

\begin{tabular}{|c|c|c|c|c|c|c|c|c|c|c|c|c|c|c|c|c|c|c|c|c|}
\hline \multirow{2}{*}{$\begin{array}{l}\text { Terminat } \\
\text { nonth }\end{array}$} & \multirow{2}{*}{ म्न } & \multirow[b]{2}{*}{479} & \multirow[b]{2}{*}{$5+79$} & \multirow[b]{2}{*}{ 6-7s } & \multirow[b]{2}{*}{779} & \multirow[b]{2}{*}{$8-79$} & \multirow[b]{2}{*}{$9-79$} & \multicolumn{5}{|c|}{ Initfat month } & \multirow[b]{2}{*}{360} & \multirow[b]{2}{*}{480} & \multirow[b]{2}{*}{$\$ 80$} & \multirow[b]{2}{*}{680} & \multirow[b]{2}{*}{780} & \multirow[b]{2}{*}{800} & \multirow[b]{2}{*}{980} & \multirow{2}{*}{$\begin{array}{l}\text { biltont } \\
\text { dotlors }\end{array}$} \\
\hline & & & & & & & & 1079 & $11-79$ & $12-79$ & $1-00$ & $2-80$ & & & & & & & & \\
\hline 479 & 68 & & & & & & & & & & & & & & & & & & & 142,3 \\
\hline 870 & 14 & 61 & & & & & & & & & & & & & & & & & & 1430 \\
\hline 619 & 82 & 28 & 96 & & & & & & & & & & & & & & & & & 1441 \\
\hline 78 & 85 & 04 & 96 & 96 & & & & & & & & & & & & & & & & 452 \\
\hline 879 & 9 & 91 & 102 & 104 & 143 & & & & & & & & & & & & & & & 465 \\
\hline 87 & 93 & 94 & 102 & 104 & 108 & 103 & & & & & & & & & & & & & & 147 \\
\hline 1029 & 98 & 99 & 107 & 110 & 115 & 10 & 129 & & & & & & & & & & & & & 1402 \\
\hline 110 & 38 & 86 & 93 & 92 & 91 & 84 & 78 & 24 & & & & & & & & & & & & 149 \\
\hline $2-19$ & 89 & 89 & 93 & 92 & 92 & $\mathrm{~B} 6$ & 81 & 58 & 92 & & & & & & & & & & & 1506 \\
\hline 180 & 80 & 19 & 82 & 80 & 17 & 70 & 62 & 41 & 49 & 08 & & & & & & & & & & 1507 \\
\hline 280 & 94 & 84 & 97 & 85 & 8,4 & 79 & 15 & 62 & 14 & 65 & 126 & & & & & & & & & 152 \\
\hline 360 & 83 & 82 & 84 & 80 & 82 & 4 & 13 & 62 & 12 & 65 & 95 & 65 & & & & & & & & 1500 \\
\hline 480 & 18 & 17 & 79 & 17 & 15 & 70 & 60 & 86 & 62 & 4 & 71 & 4 & 24 & & & & & & & 1533 \\
\hline 580 & 76 & 78 & 76 & 14 & 12 & 08 & 64 & 5 & 60 & 33 & 64 & 45 & 36 & 48 & & & & & & 1509 \\
\hline 080 & 77 & 17 & 18 & 76 & 75 & 11 & 67 & 60 & 6, & 61 & 12 & 88 & 56 & 73 & 0 & & & & & $455 t$ \\
\hline 780 & 19 & 79 & 80 & 19 & 17 & 14 & 11 & 65 & 70 & 07 & 71 & 69 & 68 & 83 & 102 & $10 s$ & & & & 1564 \\
\hline 680 & 84 & 84 & 85 & 84 & 84 & 81 & 18 & 14 & 80 & 19 & 89 & 83 & 87 & 103 & 122 & 135 & 165 & & & 1584 \\
\hline 960 & $\mathrm{8} 5$ & 85 & 86 & 86 & 8,5 & 83 & 81 & 17 & 82 & 0 & 91 & 86 & 89 & 103 & 117 & 124 & 139 & 100 & & 1597 \\
\hline $10-80$ & 85 & 85 & $8+$ & 86 & 86 & 84 & 82 & 78 & 83 & 83 & 91 & 87 & 90 & 102 & 113 & 116 & 120 & 90 & 94 & 1609 \\
\hline
\end{tabular}

Table 2

New Adjusted Monetary Base

(compounded annual rates of change, seasonally adjusted)

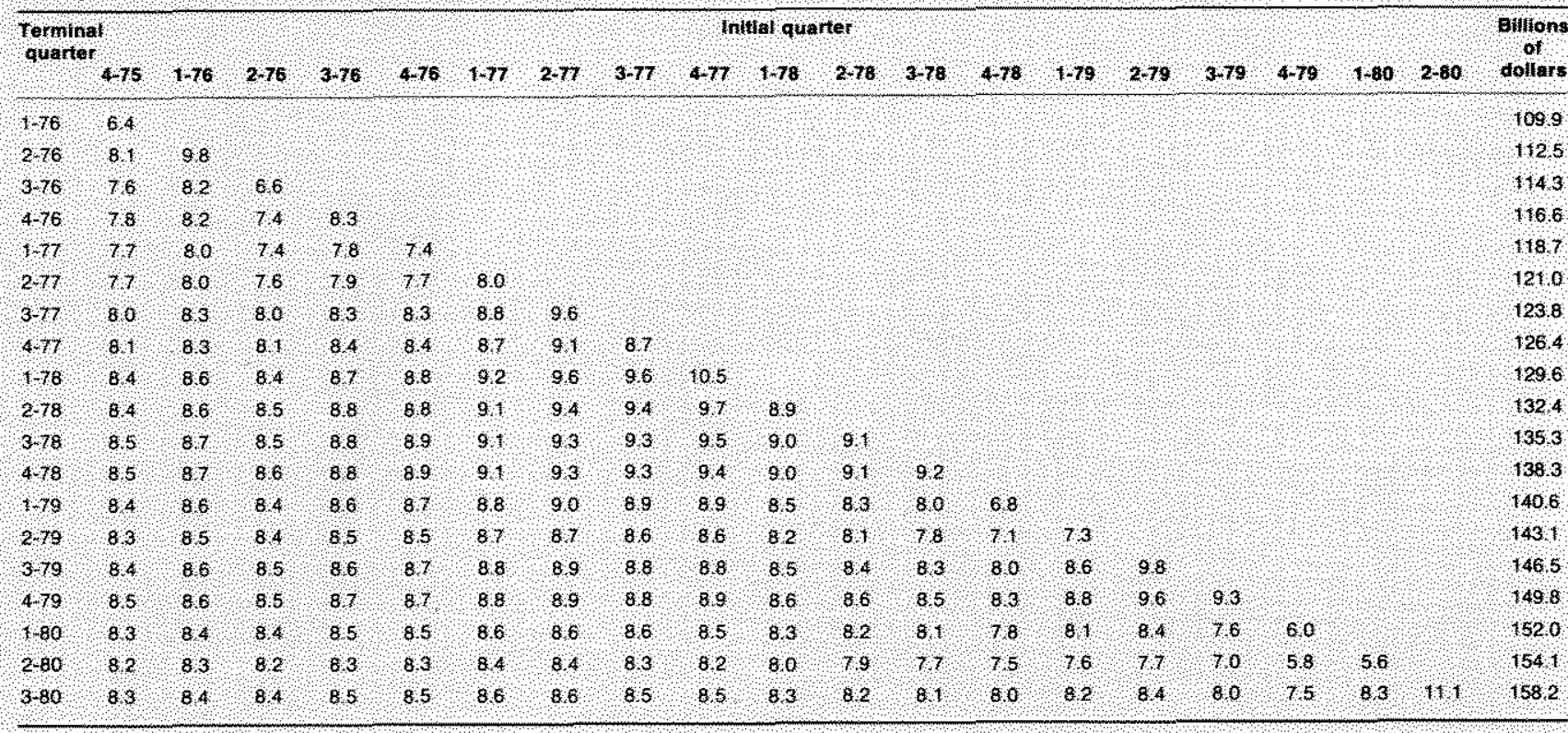




\section{Table 3}

Old Adjusted Monetary Base

(compounded annual rates of change, seasonally adjusted)

\begin{tabular}{|c|c|c|c|c|c|c|c|c|c|c|c|c|c|c|c|c|c|c|c|c|}
\hline $\begin{array}{l}\text { Tormina } \\
\text { month }\end{array}$ & मे & 479 & $5-70$ & 679 & 170 & 870 & 970 & $10-79$ & $11-79$ & $16 \mathrm{moc}$ & $1=00$ & 280 & 380 & 480 & 860 & $6+80$ & 780 & 800 & 960 & $\begin{array}{l}\text { BHor } \\
\text { coltars }\end{array}$ \\
\hline $47 s$ & 86 & & & & & & & & & & & & & & & & & & & 1452 \\
\hline 50 & 8 & 59 & & & & & & & & & & & & & & & & & & 1459 \\
\hline 679 & 86 & 66 & 12 & & & & & & & & & & & & & & & & & 1412 \\
\hline $7+79$ & 92 & 94 & 112 & 111 & & & & & & & & & & & & & & & & 1485 \\
\hline $8-79$ & 94 & 8 & 108 & 106 & 101 & & & & & & & & & & & & & & & 1497 \\
\hline 940 & 98 & 0,0 & 11 & 110 & 140 & 118 & & & & & & & & & & & & & & 1511 \\
\hline $10-9$ & 99 & 102 & 140 & 110 & 109 & 43 & 100 & & & & & & & & & & & & & 1524 \\
\hline 1179 & 93 & 04 & 100 & 97 & 94 & 91 & 18 & 48 & & & & & & & & & & & & 1530 \\
\hline 1279 & 9 & 97 & 102 & 100 & 90 & 97 & 90 & 801 & 116 & & & & & & & & & & & 1441 \\
\hline 180 & 90 & 90 & 9,4 & 91 & 86 & 85 & 17 & 67 & ? & 30 & & & & & & & & & & 1509 \\
\hline 200 & 90 & 81 & 9,4 & 82 & 80 & 87 & 08 & 14 & $8 \%$ & 68 & 97 & & & & & & & & & 1561 \\
\hline 380 & 89 & 80 & 92 & 80 & 67 & 83 & 80 & 74 & 80 & 69 & 84 & 18 & & & & & & & & 1470 \\
\hline 480 & 8.4 & 8, & 86 & 04 & 81 & 48 & 13 & 67 & 70 & 58 & 60 & $8 \%$ & 84 & & & & & & & 1574 \\
\hline $5-80$ & 81 & 81 & 83 & 80 & 77 & 14 & 69 & $6 \%$ & 80 & $5 \%$ & 81 & 50 & 139 & 43 & & & & & & 3500 \\
\hline $6-80$ & 83 & 83 & 84 & 8 & 80 & 17 & 13 & 69 & 12 & 04 & 10 & 63 & 60 & 78 & 103 & & & & & $150 \%$ \\
\hline 780 & 84 & 86 & 86 & 84 & 81 & 80 & 176 & 12 & 175 & 10 & 17 & 12 & 10 & 84 & 103 & 102 & & & & 1600 \\
\hline 800 & 88 & 86 & 90 & 80 & 87 & 86 & 83 & 80 & 84 & 80 & 66 & 84 & 80 & 100 & 119 & 127 & 152 & & & 1625 \\
\hline 880 & 90 & 90 & 92 & 9 & 80 & 08 & 86 & 84 & 88 & 8,5 & 90 & 80 & 92 & 106 & 120 & 126 & 10.8 & 125 & & 464 \\
\hline 1000 & 80 & 80 & 9 & 89 & 86 & 01 & 85 & 83 & 86 & 83 & 6.8 & 60 & 89 & 99 & 810 & 111 & 144 & 16 & 68 & 1640 \\
\hline
\end{tabular}

Table 4

\section{Old Adjusted Monetary Base}

(compounded annual rates of change, seasonally adjusted)

\begin{tabular}{|c|c|c|c|c|c|c|c|c|c|c|c|c|c|c|c|c|c|c|c|c|}
\hline Tethonto & 4 & 176 & 276 & 376 & 476 & 127 & $2+7$ & 37 & 47 & 146 & 20 & $3-78$ & 478 & 179 & 2779 & 379 & 479 & 180 & 180 & $\begin{array}{l}\text { Ellons } \\
\text { oollars }\end{array}$ \\
\hline 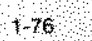 & 87 & & & & & & & & & & & & & & & & & & & 118 \\
\hline 275 & 95 & 104 & & & & & & & & & & & & & & & & & & 146 \\
\hline 376 & 87 & 88 & 12 & & & & & & & & & & & & & & & & & 106 \\
\hline $4-76$ & 85 & $8 \mathrm{~s}$ & 18 & 18 & & & & & & & & & & & & & & & & 1100 \\
\hline $1-7$ & 82 & 8 & 14 & 10 & 13 & & & & & & & & & & & & & & & 1209 \\
\hline 277 & 84 & 84 & 18 & 81 & 62 & 82 & & & & & & & & & & & & & & 1236 \\
\hline 377 & 86 & 86 & 02 & 8 & 87 & 93 & 91 & & & & & & & & & & & & & 1265 \\
\hline 477 & 86 & 86 & 83 & 85 & 87 & 9 & 9 & 85 & & & & & & & & & & & & 129 \\
\hline $1-7 \mathrm{~s}$ & 80 & 89 & 86 & 89 & 9 & 86 & 91 & 97 & 110 & & & & & & & & & & & 1325 \\
\hline 278 & 80 & 6, & 87 & 89 & 9 & 94 & 94 & 94 & 88 & 87 & & & & & & & & & & 135 \\
\hline $3-78$ & 89 & 89 & 87 & 8 & 9 & 94 & 9 & 9 & 92 & 91 & 85 & 9 & & & & & & & & 1384 \\
\hline $4-78$ & 89 & 89 & 88 & 8 & 9 & 94 & 94 & 93 & 98 & 91 & 92 & 90 & & & & & & & & 1414 \\
\hline 1779 & $8 \pi$ & 87 & 86 & 87 & 88 & 00 & 90 & 89 & 89 & 85 & 84 & 18 & 61 & & & & & & & 143 \\
\hline $2+79$ & 86 & 86 & 84 & 85 & 86 & 88 & 87 & 86 & 86 & 81 & 80 & 15 & 80 & 68 & & & & & & 146 \\
\hline 379 & 87 & 87 & 86 & 87 & 88 & 10 & 80 & 80 & 89 & 85 & 85 & 82 & 80 & 8 & $10 \mathrm{~s}$ & & & & & 1698 \\
\hline 479 & 8.8 & 80 & 87 & 8.8 & 89 & 00 & 90 & 89 & 90 & 67 & $\mathrm{~s} 7$ & 85 & 84 & 90 & 101 & 9 & & & & 1530 \\
\hline 150 & 87 & 87 & 86 & 87 & 87 & 89 & 88 & 37 & 88 & 85 & 85 & 0 & 02 & 86 & $\$$ & 04 & 12 & & & 1560 \\
\hline 280 & 85 & 8.5 & 24 & 65 & 85 & 86 & 86 & 85 & 85 & 12 & 8 & 19 & 18 & 80 & 83 & 15 & 68 & 58 & & 1582 \\
\hline 380 & 87 & 81 & 85 & 86 & 87 & 86 & 80 & 8,2 & 81 & 85 & 85 & 80 & 82 & 05 & 88 & 84 & 80 & 8, & 100 & I 624 \\
\hline
\end{tabular}




\section{Table 5}

New Adjusted Bank Reserves

(compounded annual rates of change, seasonally adjusted)

\begin{tabular}{|c|c|c|c|c|c|c|c|c|c|c|c|c|c|c|c|c|c|c|c|c|}
\hline \multirow{2}{*}{$\begin{array}{l}\text { Termina } \\
\text { month }\end{array}$} & \multirow{2}{*}{$\begin{array}{r}1 \\
3-79\end{array}$} & \multirow[b]{2}{*}{479} & \multirow[b]{2}{*}{$5-79$} & \multirow[b]{2}{*}{$6-79$} & \multirow[b]{2}{*}{$7+79$} & \multirow[b]{2}{*}{ 8-79: } & \multirow[b]{2}{*}{$9-79$} & \multicolumn{5}{|c|}{ Intial month } & \multirow[b]{2}{*}{$3-80$} & \multirow[b]{2}{*}{$4-80$} & \multirow[b]{2}{*}{$5-80$} & \multirow[b]{2}{*}{$6-80$} & \multirow[b]{2}{*}{$7-80$} & \multirow[b]{2}{*}{$8-80$} & \multirow[b]{2}{*}{$9-80$} & \multirow{2}{*}{$\begin{array}{l}\text { Brllon: } \\
\text { of } \\
\text { detlans }\end{array}$} \\
\hline & & & & & & & & $10-79$ & $11-79$ & 1279 & 180 & 2460 & & & & & & & & \\
\hline $4-79$ & 12 & & & & & & & & & & & & & & & & & & & 421 \\
\hline $5-79$ & 5.9 & 0.0 & & & & & & & & & & & & & & & & & & 421 \\
\hline $6-79$ & 5.9 & 29 & 59 & $\therefore$ & & & & . & & & & & & & & & & & & 42.3 \\
\hline $7-70$ & 6.6 & 48 & 7,3 & 9.9 & & & & & $\therefore$ & & : & & & & & & & & & 426 \\
\hline $9-79$ & 6.4 & 51 & 6.8 & 7.3 & 58 & & & & & . & & & & & & & & 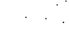 & & 428 \\
\hline $9-79$ & 6.3 & 52 & 66 & 68 & 58 & 58 & & & & & $\cdot$ & & & & & & & & & 43.0 \\
\hline 1079 & 8.4 & 7.7 & 94 & 103 & 107 & 13.3 & 214 & & & & & & & & & & & & & 43.7 \\
\hline $11-79$ & 69 & 6.2 & 7.3 & 75 & $7: 2$ & 77 & 8.7 & -27 & & & & & 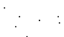 & & & & & & & 43.6 \\
\hline $2-79$ & 84 & 79 & 81 & 97 & 98 & 109 & 127 & 85 & 211 & & & & & & & & & & & 443 \\
\hline 180 & 49 & 41 & $4 \pi$ & $4: 5$ & 38 & 34 & 28 & 27 & 27 & -216 & $\therefore$ & & $\therefore$ & & & & & . & & 43.4 \\
\hline 280 & 6.3 & 57 & 0.4 & 65 & 63 & 62 & 62 & 28 & 47 & 27 & $2+2$ & & & & & & & & 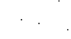 & 44.1 \\
\hline 380 & 58 & 52 & 57 & $5 t$ & 53 & 50 & 52 & 2 & 35 & 18 & 101 & 0.0 & $\because$ & & & & & $\therefore$ & & 44.7 \\
\hline $4-80$ & 57 & 52 & 57 & 57 & 54 & 53 & 52 & 28 & 39 & 00 & 86 & 28 & 56 & & & & & & & 44.3 \\
\hline 580 & 48 & 37 & 40 & 39 & 34 & 31 & 28 & 0.4 & 09 & -27 & 28 & -27 & -0 & -12.7 & & & & & & 43.8 \\
\hline $6-80$ & 46 & 41 & 44 & 43 & 38 & 37 & 34 & 14 & 20 & 09 & 39 & 0.0 & 0.0 & -27 & 8.5 & & & & & 441 \\
\hline 780 & 48 & 43 & 47 & 46 & 42 & 41 & 39 & 21 & 28 & 0.4 & 4.7 & 16 & 2.1 & 0.9 & 8.5 & 8.5 & & & & 44.4 \\
\hline $8 \% 80$ & 55 & 51 & 55 & 54 & 52 & 51 & 51 & 36 & 43 & 24 & 64 & 4.1 & 5.0 & 4.8 & 14.4 & 129 & $\$ 7.5$ & & & 45.0 \\
\hline 980 & 65 & 61 & 65 & 66 & 64 & 65 & 6.5 & 53 & 67 & 4.5 & 8.4 & 6.7 & 7.9 & 8.3 & 143 & 96.3 & 20.5 & 23.5 & & 45.8 \\
\hline $10-80$ & 61 & 58 & 61 & 61 & 60 & 60 & 60 & 48 & 55 & 4.1 & 7.4 & 5.8 & 6.7 & 6.9 & 11.3 & 12.0 & 13.2 & $\$ 1.2$ & 0.0 & 45. \\
\hline
\end{tabular}

Table 6

New Adjusted Bank Reserves

(compounded annual rates of change, seasonally adjusted)

\begin{tabular}{|c|c|c|c|c|c|c|c|c|c|c|c|c|c|c|c|c|c|c|c|c|}
\hline \multirow{2}{*}{$\begin{array}{l}\text { Terminal } \\
\text { quarter }\end{array}$} & \multirow{2}{*}{$4-73$} & \multirow[b]{2}{*}{$1-76$} & \multirow[b]{2}{*}{$2-76$} & \multirow[b]{2}{*}{$3-76$} & \multirow[b]{2}{*}{$4-76$} & \multirow[b]{2}{*}{1.77} & \multirow[b]{2}{*}{$2-77$} & \multicolumn{5}{|c|}{ Initial quarter } & \multirow[b]{2}{*}{$4-78$} & \multirow[b]{2}{*}{$1-79$} & \multirow{2}{*}{ 2.79 } & \multirow[b]{2}{*}{$3-79$} & \multirow[b]{2}{*}{$4-79$} & \multirow[b]{2}{*}{$1-80$} & \multirow[b]{2}{*}{280} & \multirow{2}{*}{$\begin{array}{l}\text { Biflons } \\
\text { of } \\
\text { dollars }\end{array}$} \\
\hline & & & & & & & & $3-77$ & $4 \times 77$ & $1-78$ & $2-78$ & $3-78$ & & & & & & & & \\
\hline$f-36$ & 0.0 & & & & & & & & & & & & & . & & & & & & 349 \\
\hline $2-76$ & 35 & 7.1 & & & & & & & & & & & & & & & & & & 35.5 \\
\hline $3-76$ & 2.7 & 4.1 & 1.1 & & & & & & & & & & & & & & & & & 356 \\
\hline $4-76$ & 4.0 & 5.4 & $\$ .6$ & 8.1 & & & & & & & & $\therefore$ & & & & & & & & 36.3 \\
\hline $1-77$ & 4.3 & 5.4 & 4.9 & 6.9 & 5.6 & & & & & & & $\therefore$ & . & & & & & & & 368 \\
\hline $2-77$ & 4.7 & 5.7 & 5.4 & 68 & 6.2 & 6.7 & & & & & & . & $\therefore$ & & & & & & & 37.4 \\
\hline $3-77$ & 5.1 & 60 & 5.8 & 7.0 & 6.7 & 7.2 & 7.7 & & & $\therefore$ & & . & & & & & & & & $38 . t$ \\
\hline $4-77$ & 50 & 5.8 & 5.6 & 6.5 & 6.1 & 6.2 & 6.0 & 4.3 & & & . & & & & & & & & & 38.5 \\
\hline $1-78$ & 5.8 & 6.5 & 6.4 & 7.4 & 7.2 & 76 & 79 & 8.0 & $1+9$ & & & & & & & & & & & 39.6 \\
\hline $2+78$ & 60 & 6.7 & 6.7 & 7.5 & 7.4 & 7.8 & 8,0 & 8.1 & 10.1 & 83 & & & & & & & & & & 40,4 \\
\hline $3-76$ & 62 & 6.9 & 6.8 & 76 & 7.5 & 7.8 & 8.0 & e.1 & 9.5 & 8.2 & 8.2 & & & & & & & & & 412 \\
\hline $4-78$ & 6.0 & 6.6 & 6.5 & 7.2 & 7.7 & 7.3 & $74:$ & 7,3 & 8.1 & 68 & 6.0 & 39 & & & & & & & & 416 \\
\hline+79 & 5.6 & 6.1 & 60 & 6.5 & 64 & 8.4 & 6.4 & 6.2 & 5.6 & 53 & 43 & 24 & 10 & & & & & & & 417 \\
\hline $2-79$ & 5.6 & 6.0 & 5.9 & 6.4 & 6.2 & 6.3 & 6.2 & 6,0 & 6.3 & 5.2 & 4.5 & 32 & 29 & 49 & & & & & & 42.2 \\
\hline 3.79 & 5.6 & 60 & 5.9 & 6.3 & 62 & 6.2 & 6.2 & 60 & 62 & 5.3 & 47 & 39 & 39 & 53 & 58 & & & & & 428 \\
\hline $4-79$ & 5.9 & 6.3 & 63 & 67 & 6.5 & 6.6 & 6.6 & 6.5 & 6.8 & 61 & 57 & 52 & 5.5 & 71 & 82 & 107 & & & & 439 \\
\hline $1-80$ & $E_{5.5}$ & 5.9 & 5.8 & 6.2 & $60^{\circ}$ & 6.1 & 6.0 & 5.8 & 6.0 & 5.3 & 49 & 43 & 44 & 5.3 & 54 & 52 & 00 & & & 43.9 \\
\hline $2-80$ & 5.3 & 57 & 5.6 & 5.9 & 57 & 57 & 5.6 & 5.5 & 56 & 4.9 & 4.5 & 400 & 40 & 46 & 45 & 4, & 09 & 18 & & 44 \\
\hline $3-80$ & 5.5 & 5.9 & 5.8 & 6.1 & 6.0 & 60 & 59 & 5.8 & 59 & 5.3 & 5.0 & 40 & 4,7 & 5.4 & 55 & 54 & 37 & 55 & 94 & 45 \\
\hline
\end{tabular}




\section{Table 7}

Old Adjusted Bank neserves

(compounded annual rates of change, seasonally adjusted)

\begin{tabular}{|c|c|c|c|c|c|c|c|c|c|c|c|c|c|c|c|c|c|c|c|c|}
\hline \multirow{2}{*}{ remonth } & \multirow{2}{*}{$\begin{array}{l}1,5 \\
3\end{array}$} & \multirow[b]{2}{*}{479} & \multirow[b]{2}{*}{579} & \multirow[b]{2}{*}{679} & \multirow[b]{2}{*}{779} & \multirow[b]{2}{*}{879} & \multirow[b]{2}{*}{979} & \multicolumn{4}{|c|}{ Httlat month } & \multirow[b]{2}{*}{280} & \multirow[b]{2}{*}{$3-80$} & \multirow[b]{2}{*}{480} & \multirow[b]{2}{*}{80} & \multirow[b]{2}{*}{$6-90$} & \multirow[b]{2}{*}{180} & \multirow[b]{2}{*}{$8-6 \theta$} & \multirow[b]{2}{*}{940} & \multirow{2}{*}{$\begin{array}{l}\text { Bulan } \\
\text { of }\end{array}$} \\
\hline & & & & & & & & $10-79$ & 1117 & 1270 & 180 & & & & & & & & & \\
\hline 479 & 113 & & & & & & & & & & & & & & & & & & & 450 \\
\hline 579 & 5 & 00 & & & & & & & & & & & & & & & & & & 480 \\
\hline 679 & 74 & 55 & 12 & & & & & & & & & & & & & & & & & 454 \\
\hline 770 & 90 & 82 & 126 & 140 & & & & & & & & & & & & & & & & 459 \\
\hline 879 & 72 & 68 & 92 & 82 & 26 & & & & & & & & & & & & & & & 460 \\
\hline 979 & 82 & 16 & 96 & 91 & 67 & 109 & & & & & & & & & & & & & & 46 \\
\hline 1070 & 90 & 86 & 104 & 102 & 90 & 120 & 101 & & & & & & & & & & & & & 469 \\
\hline 149 & 8 & 81 & 96 & 92 & 80 & 99 & 94 & 52 & & & & & & & & & & & & 41 \\
\hline $12+9$ & 106 & 105 & 121 & 122 & 119 & 143 & 15 & 164 & 287 & & & & & & & & & & & 481 \\
\hline 1,80 & a) & 18 & 80 & 8 & 15 & 68 & 80 & $\diamond$ & 65 & 118 & & & & & & & & & & 476 \\
\hline 2,80 & 83 & 8 & 90 & 87 & 80 & 89 & 85 & 12 & 19 & 12 & 106 & & & & & & & & & 480 \\
\hline 380 & 78 & 15 & 83 & 80 & 13 & 80 & 13 & 03 & 68 & 000 & 65 & 25 & & & & & & & & 491 \\
\hline 480 & 38 & 10 & 83 & 80 & 23 & 79 & 75 & 0.5 & 68 & 19 & 69 & 51 & t? & & & & & & & 48,4 \\
\hline 5,60 & 63 & 59 & 64 & 60 & 33 & 85 & 49 & 37 & 34 & 10 & 10 & 80 & 25 & 41 & & & & & & 479 \\
\hline 840 & 86 & 63 & 00 & 64 & 37 & 60 & 58 & 4 & 4 & 06 & 36 & 19 & ४ै & 12 & 10 & & & & & 403 \\
\hline 780 & 67 & 64 & 68 & 65 & 50 & 62 & 57 & 40 & 48 & 18 & 42 & 30 & 32 & 11 & 9 & 17 & & & & 480 \\
\hline 800 & 80 & 68 & 12 & 69 & 64 & 67 & 64 & 57 & 37 & 3 & 55 & 46 & 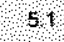 & 4,4 & 104 & 104 & 131 & & & 49 \\
\hline 980 & 82 & 80 & 85 & 84 & 80 & 84 & 82 & 77 & 19 & 59 & 83 & 80 & 89 & 12 & 151 & 167 & 215 & 30.5 & & 502 \\
\hline 1060 & 13 & 11 & 16 & 13 & 6.9 & 12 & 69 & 6 & 65 & 43 & 65 & 60 & 65 & 63 & 103 & 103 & 111 & 102 & & 499 \\
\hline
\end{tabular}

Table 8

\section{Od Adusted Bank Reserves}

\section{(compounded annual rates of change, seasonally adjusted)}

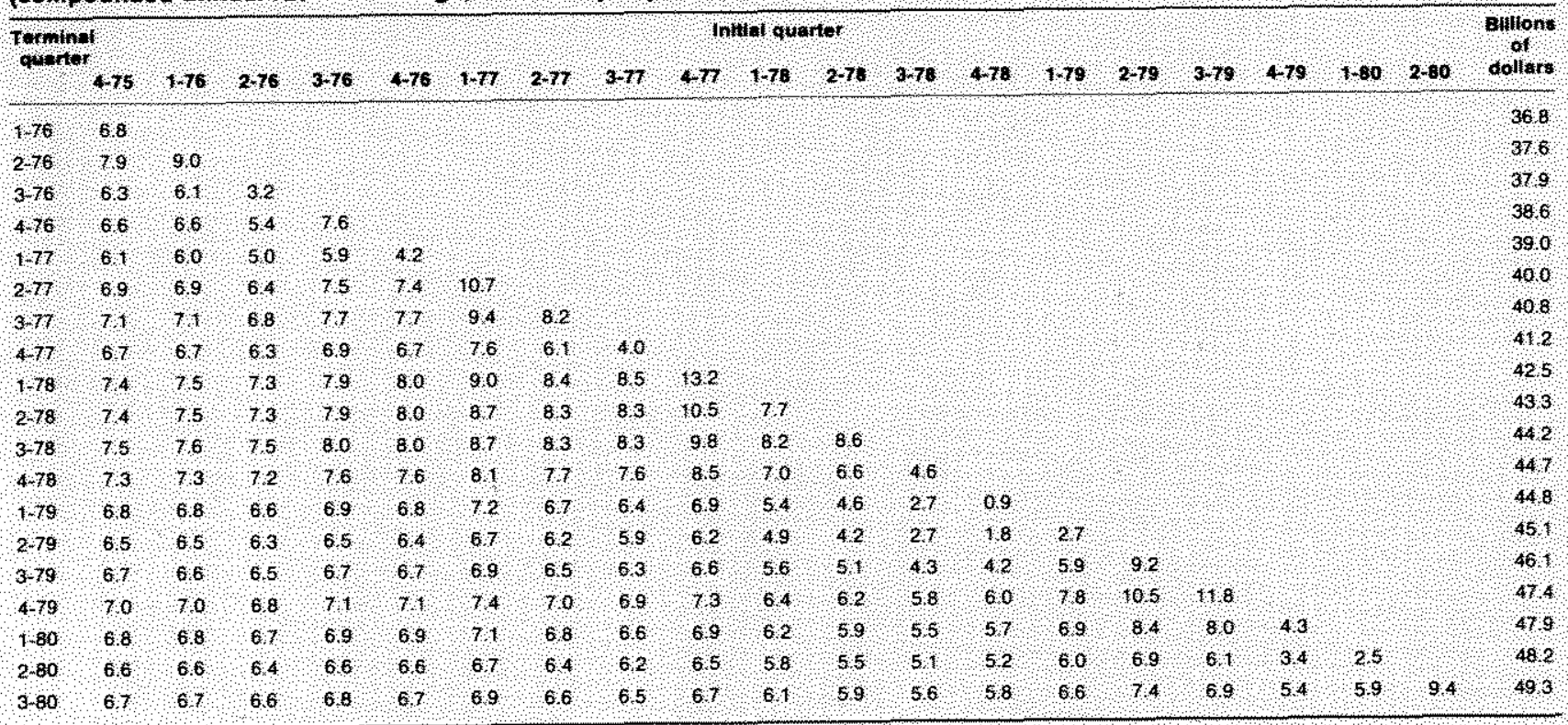

